agriculture and trade. Most of these reports are by Mr. C. J. Jonington, but several other writers have collaborated in the work. The Andaman population of 19,000 shows an increase, but this increase is solely in the convict and other immigrant population. The aborigines have fallen in number to $460 \mathrm{com}$ pared with 786 ten years ago, 1,317 in 1911, and nearly 5,000 when contact with an introduced population began in 1858 . There seems to be little hope of these races surviving. On the other hand, in the Nicobars, where there has been little disturbance with the natives or their tribal systems, the aboriginal population shows a steady increase during the last thirty years and is now nearly 10,000 . The figures in several of the islands are based on estimates but there is no reason to doubt their accuracy.

\section{Sterility in Domesticated Animals}

A USEFuL bulletin has been issued from the Imperial Bureau of Animal Genetics, Edinburgh, $(2 s .6 d$.$) , on the physiological and genetical aspects$ of sterility in domesticated animals. It is written by Dr. William Orr and Dr. F. Fraser Darling, and a full bibliography, prepared by Miss M. V. Cytovich, is appended. Succossive sections deal with physiological aberrations in the reproductive system, the nutritional aspects of sterility, and types of sterility referable to genetical causes. This will be of service not only to all those engaged in practical animal breeding kut also to those engaged in research on the physiological or genetical aspects of animal sterility.

\section{Centenary of Sir John Kirk}

IN connexion with the centenary on December 19 of Sir John Kirk (see Nature, 130, 920, Dec. 17, 1932), a portrait of Kirk was unveiled at the Zanzibar Museum, Zanzibar, by Sir Richard Rankine, British Resident for the Protectorate, in the presence of His Highness the Sultan. A number of exhibits associated with Sir John Kirk were displayed at the ceremony.

\section{Effect of the Preying of Birds on Butterflies}

Mr. C. L. Collenette writes from the Entomological Department, British Museum (Natural History), South Kensington, London, S.W.7, that he is making an investigation into the extent to which butterflies in the perfect or imaginal state are preyed upon in the British Isles by birds, and he would be glad to have any first-hand observations, giving, where possible, the species of both butterfly and bird, the date and locality, details of mode of capture, etc. Wings detached by the bird are of value, both as evidence of identity, and also by reason of the imprint of the bird's beak which is sometimes shown. Published records up to and including the year 1908 have been summarised in a paper by Sir Guy Marshall entitled, "Birds as a Factor in the Production of Mimetic Resemblances among Butterflies" (Trans. Ent. Soc. Lond., 329-383, 1909). Mr. Collenette is making a search in both entomological and ornithological literature for British records published since this date, and he would be pleased to receive references especially in the lesser-known publications.

\section{Announcements}

A Discussion on "The Raman Effect in Relation to Some Chemical Problems", to be opened by Dr. J. J. Fox, will be held at the Chemical Society on February 16, at 8 P.M.

Dr. S. Courtauld, a trustee of the National Gallery and founder of the Courtauld Institute of Art, Mr. E. G. V. Knox, editor of Punch, and Dr. N. V. Sidgwick, F.R.S., fellow of Lincoln College, Oxford, and member of the Advisory Council of Scientific and Industrial Research, have been elected members of the Athenæum under the provisions of Rule II of the Club, which empowers the annual election by the Committee of a certain number of persons of distinguished eminence in science, literature, the arts or for public service.

THE next sectional meeting of the World Power Conference will be held at Stockholm on June 28July 4. Reference was made to the programme in connexion with this meeting in NATURE of January 7, p. 22. Forms of application for membership can be obtained from the British National Committee, World Power Conference, 63, Lincoln's Inn Fields, London, W.C.2.

The following have been elected officers of the Royal Meteorological Society for 1933 :-President : Prof. S. Chapman; Hon. Treasurer: Mr. R. A. Watson Watt ; Hon. Secretaries : Dr. J. Glasspoole; Mr. W. M. Witchell, and Dr. A. Crichton Mitchell; Foreign Secretary: Capt. C. J. P. Cave; New Members of Council : Mr. J. H. Field, Dr. B. A. Keen, Capt. W. N. McClean, and Dr. F. J. W. Whipple.

THE Central Scientific Company of Chicago has issued the first two numbers of a bulletin entitled Cenco News Chats which is meant to furnish to the public interested in instruments an up-to-date account of new developments in apparatus for which the Company is responsible. It is less formal than a catalogue, is well illustrated and does not enter into scientific details. We learn from it that the Bunsen burner with an $\mathrm{H}$ base with side entrance for gas and bottom for air is the most popular, and that the wire gauze over the flame should be iron 16 mils in diameter and 16 to the inch. Spectra photographed by means of a Wallace concave grating replica with a ruled surface only $28 \mathrm{~mm}$. by $20 \mathrm{~mm}$. are reproduced, and a short account of the Hahn X-ray spectrograph is given. Copies of the News Chats may be obtained on request from Messrs. Edwards, Allendale Road, London, S.E.5.

Applicatrons are invited for the following appointments, on or before the dates mentioned :-A temporary inspector in the Markets Division of the Ministry of Agriculture and Fisheries-The Secretary, Ministry of Agriculture and Fisheries, 10, Whitehall Place, London, S.W.1 (Feb. 20). A principal and head master of the Maidstone Technical Institute and Junior Technical School-Mr. A. W. Peacock, Education Department, Tonbridge Road, Maidstone (Feb. 25 ). 